\title{
AMPHIDROMY AND MIGRATIONS OF FRESHWATER SHRIMPS. I. COSTS, BENEFITS, EVOLUTIONARY ORIGINS, AND AN UNUSUAL CASE OF AMPHIDROMY
}

\author{
BY \\ RAYMOND T. BAUER ${ }^{1}$ ) \\ Department of Biology, University of Louisiana at Lafayette, Lafayette, \\ Louisiana 70504-2451, U.S.A.
}

\begin{abstract}
Many freshwater shrimps (Decapoda, Caridea) have amphidromous life histories, with extended planktonic larval development in the sea. Larvae either are hatched upstream to drift down to the sea or are carried and released there by females. After development, postlarvae (juveniles) must migrate back up to their adult freshwater habitat. An amphidromous life cycle thus involves long distance migrations between marine and fresh waters. Other freshwater shrimps have abbreviated (or direct) larval development (ALD) with a completely freshwater life cycle and without such migrations. The question of which life history pattern (amphidromy versus ALD) is ancestral in freshwater shrimps is discussed in terms of costs, benefits, and phylogeny. Competing hypotheses are presented to explain the unusual distribution of Macrobrachium ohione, an amphidromous shrimp with recently abundant populations located very far $(>1500 \mathrm{~km})$ from the sea.
\end{abstract}

\section{INTRODUCTION}

Although the majority of caridean shrimps are marine, approximately $25 \%$ of the 3200 species occur in fresh water habitats (De Grave et al., 2007, 2009). The life history of some of these species is completely adapted to fresh water in that all stages of the life cycle occur there. The extended planktonic development of most marine species is abbreviated in these freshwater species, with hatching as advanced larvae and few subsequent larval stages, or is direct, with the embryo hatching out as a postlarva (small juvenile) (Hayashi \&

\footnotetext{
1) e-mail: rtbauer@louisiana.edu 

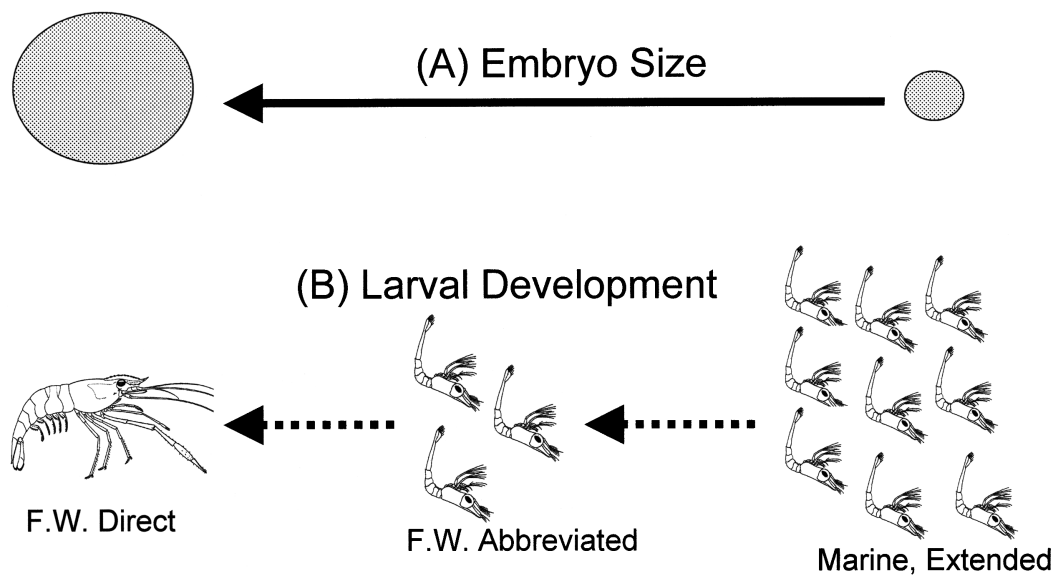

\section{ALD}

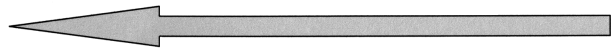

AMPHIDROMY

(C) Life History Pattern

Fig. 1. The relationship of embryo (egg) size, larval development and life history pattern in freshwater shrimps. ALD, abbreviated larval and direct development. F.W., fresh water.

Hamano, 1984; Jalihal et al., 1993). To sustain extended incubation and embryonic development before hatching in these species, mature oocytes (eggs) must contain considerable yolk. Thus, females with abbreviated larval development (ALD) spawn relatively few, large eggs (fig. 1). At the other extreme in the life history spectrum of freshwater shrimps are amphidromous species, whose larvae require development in saline waters. Larval development occurs in the brackish water of estuaries and coastal bays or in the open sea. In amphidromous species, females spawn many small eggs which hatch at a much less advanced larval stage than those of species with abbreviated or direct development, and larval development is extended, with several stages (fig. 1) and is marine planktonic (Bauer, 2004).

Amphidromy is defined as a life history cycle in which there are recurring migrations between fresh water and the sea for purposes other than reproduction (McDowall, 2007). In amphidromous freshwater shrimps, principally found in the caridean families Atyidae, Xiphocarididae, and Palaemonidae (primarily Macrobrachium spp.), females live, breed, and spawn in fresh water but the larvae must go to the sea for development. Larvae may simply be hatched and released in the upstream habitat, using river flow to drift to the sea. Alternately, females migrate downstream, carrying their brooded embryos nearer to or into coastal bays and estuaries where hatching of embryos to larvae 
takes place. After larval development in coastal or open ocean environments, the newly metamorphosed postlarvae (juveniles) must find and enter the mouth of a coastal river or stream and migrate up to the adult freshwater habitat, sometimes considerable distances from the sea. Amphidromous shrimps have received ever increasing attention in the last 2-3 decades, with studies stimulated both by basic interest in life cycles and by human impacts on their lotic habitats, especially dam construction (Holmquist et al., 1998) and diversion of stream water (March et al., 2003), which impede or completely stop the downstream transport of larvae to the sea or the subsequent "return" upstream migration of juveniles.

\section{COSTS, BENEFITS, AND ORIGINS OF AMPHIDROMY IN SHRIMPS}

Life histories of freshwater shrimps exhibit a continuum between two extremes: (a) amphidromy, with extended larval development in salt water versus (b) ALD in fresh water, with a reduction of larval stages, sometimes with direct development, with hatching as a benthic postlarva or juvenile (e.g., Magalhães \& Walker, 1988; Jalihal, 1993). Amphidromy involves long distance movements or migrations while ALD does not. Hatching stages of ALD species are benthic or nearly so and can remain in or close to the adult habitat (Magalhães \& Walker, 1988). What are the selective pressures that favor (benefits or advantages) or disfavor (costs or disadvantages) amphidromy and ALD? Obviously, ALD must evolve in freshwater species whose larvae are blocked from access to the sea or they become extinct. Such species are those which occur or become land-locked in inland waters or in which the distances to the sea are great, beyond the capacity of the lecithotrophic, non-feeding Stage-1 larva to survive until reaching the larval habitat downstream.

McDowall (2007), referring especially to fishes, made a comprehensive list of the advantages and disadvantages of amphidromy, which can be viewed in terms of shrimp biology. A major disadvantage is that the delicate hatching larvae leave the adult habitat to make a long dangerous trip down rivers or streams, sometimes in rapidly flowing, turbulent waters, to the marine environment. After development, the resulting juveniles must then run the gauntlet in reverse to get to back to the adult habitat. Mortality during these migrations is obviously high, given the large number of larvae that amphidromous species produce. However, amphidromy allows larvae access to the abundant planktonic food supply of estuarine and marine habitats. Magalhães \& Walker (1988), working on a group of Amazonian freshwater 
shrimps, showed that ALD occurred in species living in inland nutrient-poor or poorly illuminated creeks and lakes in which larval food supply (plankton) was poor or lacking.

The initial invasion of freshwater habitats by carideans may have been due a complex of selective pressures: invasion of an empty or under-occupied freshwater niche, as well as escape from marine competition and predation. The stream systems of the tropical rainforests in which many freshwater shrimps reside, such as those of the island of Puerto Rico, have a detritus-based food web with a primary organic input of leaf litter, twigs and fruit (Covich $\&$ McDowall, 1996). Atyid shrimps, with their unique scraping and filtering chela brushes, are important harvesters of detritus and periphyton. Xiphocaris elongata is a somewhat more generalized consumer (primarily a leaf-shredder) and, at a higher tropic level, Macrobrachium spp. are omnivorous scavengers and predators.

The hypothesis of "escape from fish predation" as a selective pressure which favored invasion of fresh water by shrimps has some support. McDowall (2007) suggested that the freshwater fish fauna (including predators) is highly impoverished, at least on island streams where amphidromous species are abundant. Covich et al. (2009) have shown that upstream migration by the amphidromous Atya lanipes and Xiphocaris elongata allows them access to headwater refugia which cannot be reached by stream-fish predators.

A major advantage of amphidromy is dispersal (Hunte, 1978; McDowall, 2007). As larvae develop in estuaries or the open sea, dispersal to adjacent and sometimes distant streams and rivers, sometimes on other land masses, can occur. A variety of studies on populations of amphidromous species show gene flow among populations from stream systems on the same or other land masses (Page et al., 2005, 2007, 2008; Cook et al., 2006; Mashiko \& Shy, 2008). Amphidromy allows colonization of new but similar habitats as well as recruitment back into the stream of larval origin (Hunte, 1978). The biogeography of Caribbean and Pacific atyid shrimps appears, in large part, to be a product of larval dispersal (Page et al., 2008). "Estuary hopping" (larval movement between nearby estuaries) or limited dispersal in the open sea has allowed gene flow among Indo-Australian populations of Macrobrachium rosenbergii (de Bruyn \& Mather, 2007). The broader distributions of amphidromous Macrobrachium spp. on western Pacific islands relative to related ALD species has been attributed to larval dispersal at sea (Mashiko \& Shy, 2008).

A question which has generated some controversy is: which is the plesiomorphic (ancestral) life history, amphidromy or ALD (fig. 2). The issue 


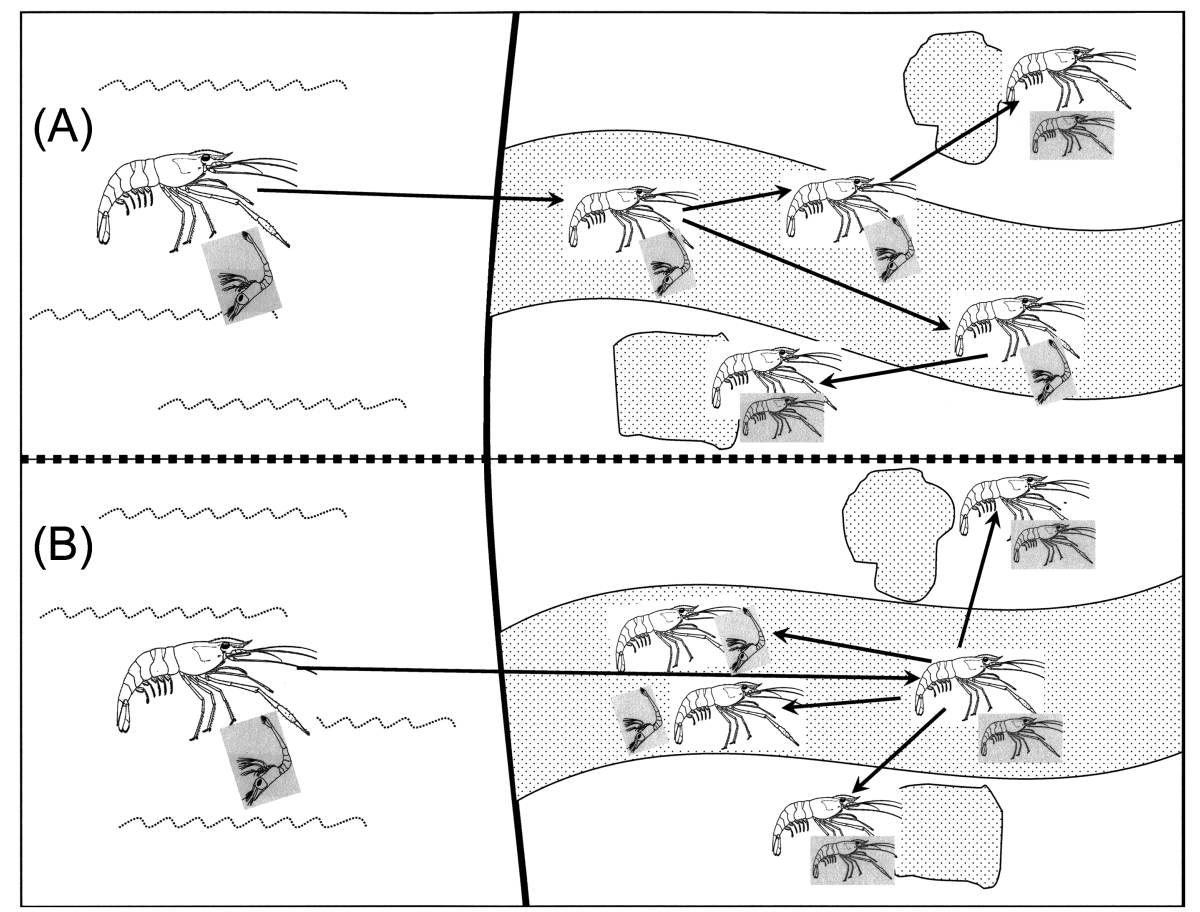

Fig. 2. Two hypotheses on the origin of amphidromy and ALD in freshwater shrimps. A, ampidromous species are derived from marine species which invade fresh water (stippled rivers and lakes to right of shoreline) and give rise to both ALD and amphidromous descendants; $\mathrm{B}$, the initially marine shrimp invaders evolve ALD upon entry into freshwater habitats and then give rise to both amphidromous and other ALD species. Species with extended larval development (marine, amphidromous) are represented by an adult plus larva (shaded), ALD species by adult and miniature adult (shaded).

must be addressed separately in the Atyidae and in the palaemonid genus Macrobrachium, in which the full range of amphidromy to ALD (or the reverse) is found. Of 41 atyid genera (De Grave et al., 2009), only 3 occur in specialized saline habitats (Bauer, 2004). These genera aside, the atyids are strictly freshwater shrimps as adults, with life histories ranging from amphidromy to direct development. Ortmann (1894) believed that atyid ancestors entered fresh water at "a very early geological period" (perhaps the Jurassic; Ortmann, 1902). He based this on their "exclusively" freshwater habits and their primitive morphology, very closely allied to that of the marine "Acanthephyridae" (now termed Oplophoridae), which he considered the most primitive caridean family (see Bauer, 2004 and Bracken et al., 2009 for more recent views on caridean phylogeny). He regarded the freshwater habits of the family as the "original man- 
ner of living". However, he was apparently unaware of the estuarine or marine larval development of many atyids.

Other students of the Atyidae also supposed that the group radiated into fresh water at an early geological age but they suspected or knew that many atyids have marine larvae. Chace \& Hobbs (1969) wrote of the "primeval Atya with its presumed marine larvae" while Hobbs \& Hart (1982) stated, based on a morphological phylogeny and the biogeography of the genus, that an Atya-like ancestor existed by the late Mesozoic (early Jurassic). Carpenter (1977) hypothesized that atyids probably originated in a shallow-water Tethys Sea in the Cretaceous. Recently, the divergence time from the most recent ancestor has been estimated independently, using molecular "clocks", as the early Jurassic for the Xiphocarididae and the mid-Jurassic for its sister group, the Atyidae (Bracken et al., in press). This view is concordant with that hypothesized by the biogeographical/morphological phylogeny studies cited above.

Pereira \& Garcia (1995) proposed the opposite evolutionary history for the other major amphidromous group, Macrobrachium spp. (Palaemonidae). In their view, the Macrobrachium ancestor was a completely freshwater shrimp with ALD which then gave rise to both ALD and amphidromous descendents. This view has received little support. One objection has to do with larval development. Amphidromous Macrobrachium spp. and atyids have extended planktonic development, as do most marine carideans. Nothing in amphidromous atyid and palaemonid larval development suggests that it is somehow significantly different from that of other marine shrimps. Extended larval development derived secondarily from ALD would presumably show some unique, recognizable features. No such features have been reported, although many descriptive studies on caridean larvae have been published. As Williamson (1982) stated in his review of decapod larval morphology and diversity, "abbreviation of larval development may certainly be regarded as a departure from the ancestral condition in Decapoda". Given the abundance, diversity, and fossil record of decapod taxa with known or presumed extended, marine, planktonic larval development, there is no reason to suppose that this is not the ancestral condition in the Decapoda including the Caridea, a primarily marine group.

Phylogenies based on gene sequences allow for an independent test of the alternative hypotheses that amphidromy or ALD is ancestral in freshwater shrimps. Some recent studies have mapped amphidromy or ALD on genebased phylogenies. Cook et al. (2006), using the COI mtDNA gene and 
biogeographical data on various populations of Paratya australiensis, showed that the amphidromy to freshwater transition has occurred several times in this species on Australia. Page et al. (2005) used molecular phylogeny to show that amphidromy is plesiomorphic to ALD in this genus Paratya. Murphy \& Austin (2004) analyzed the phylogeography of Macrobrachium from a sample of 30 species (of 238 worldwide; De Grave et al., 2009). When amphidromy and ALD were mapped on the phylogeny, 5 primarily amphidromous lineages contained derived ALD species, supporting the "amphidromy as primitive" view. However, the most basal lineages in the overall tree were ALD species, supporting the Pereira \& Garcia (1995) hypothesis. Fortunately, the hypothesis was further tested in a recent analysis of phylogeny (based on several genes) and life history evolution of 45 Asian Macrobrachium spp. by Wowor et al. (2009). The mapping of ALD and amphidromy on their phylogenetic tree clearly shows that, as in Atyidae and Xiphocarididae, amphidromy is the primitive life history trait in the genus Macrobrachium.

\section{MACROBRACHIUM OHIONE, AN UNUSUAL AMPHIDROMOUS SPECIES}

Macrobrachium ohione is exceptional in a number of ways that illustrate various aspects of amphidromous life-history migrations. It is one of six Macrobrachium species that inhabit coastal river systems emptying into the Gulf of Mexico and along the southeastern Atlantic coast of the United States (Bowles et al., 2000). All of these species have been assumed to be amphidromous (Bowles et al., 2000), primarily because of their geographic distribution and requirement of salt water for larval development (Dugan et al., 1975). Observations on one species, M. ohione, show that it is amphidromous, with both a female downstream hatching migration and an upstream juvenile migration after marine development (Bauer \& Delahoussaye, 2008). This species is extraordinary among amphidromous species around the world in the distances from the sea that upstream populations are now or were formerly abundant. Instead of maximum upstream distances of several to a few hundred kilometers from the sea, as in most amphidromous shrimps, substantial reproductive $M$. ohione populations (with embryo-bearing females) were found as recently as the 1930's and 1940's as far north as 1500-2000 km from the sea (Gulf of Mexico) in the Mississippi/Ohio River System (fig. 3) (Bowles et al., 2000; Bauer \& Delahoussaye, 2008). 


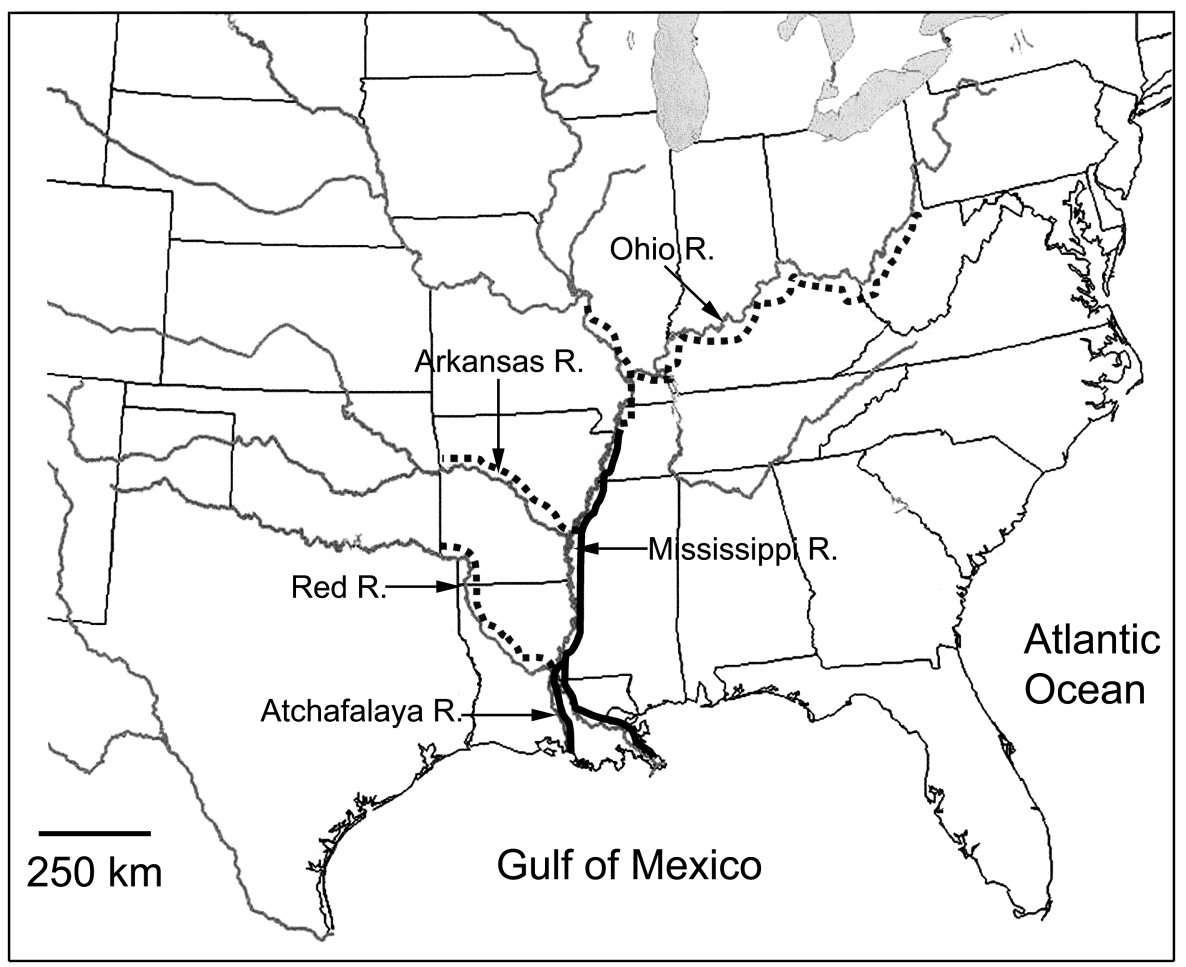

Fig. 3. The distribution Macrobrachium ohione, past (dotted lines) and present (solid dark lines), in the Mississippi River System, North America. Major rivers in the system are labeled (arrows).

Such a far-ranging distribution away from the sea in an amphidromous species (M. ohione) presents a puzzle. Is it possible that females can migrate $1500 \mathrm{~km}$ or more to release larvae in or within larval drifting distance of coastal estuaries? Various hypotheses may be proposed. One is that females from far northern populations do migrate down to the sea and that juveniles migrate back up again. An estimate of $\sim 1 \mathrm{~km} \mathrm{hr}^{-1}$ upstream swimming speed of migrating juveniles was made by Bauer \& Delahoussaye, 2008. Assuming that the nocturnally active juveniles swim upstream for $8 \mathrm{hr} \mathrm{d}^{-1}$ at this speed, it would take 6 months to cover $1500 \mathrm{~km}$. Juveniles do grow while migrating and could mature reproductively after arrival at far-upstream locations in their first year, as they do in coastal populations, and then migrate down again almost immediately, perhaps more quickly as reproductive adults swimming downstream. As the embryo incubation period at $22-23^{\circ} \mathrm{C}$ is $2-3$ weeks (Bauer $\&$ Delahoussaye, 2008), embryos would hatch far upstream before the females reach the sea, and not within the maximum $\sim 150 \mathrm{~km}$ distance that hatching (Stage-1) larvae can drift before safely reaching saline waters to continue 
development (Rome et al., 2009). Thus, a downstream female migration and return upstream juvenile migration seems implausible as a life history strategy for these far-upstream populations if life span is similar to those estimated from coastal populations (1-2 years; Truesdale \& Mermilliod, 1979).

Another hypothesis that might explain the former abundance of large populations far from the sea is that larval development is abbreviated or occurs in fresh water, eliminating the need for migrations. Larval development was not, unfortunately, studied when far-northern populations were abundant and females were readily available. However, embryo size is a good indicator of the type of larval development in shrimps (Bauer, 2004). Of five females from upstream populations (museum collections) observed, all had early embryos in the same small size range as those from a coastal amphidromous population (pers. obs.). These few observations indicate full planktonic development in far-upstream populations, like that of coastal populations. However, whether such development requires salt water needs to be tested experimentally using larvae hatched from far-upstream females.

One intriguing possibility is that larval development formerly occurred upstream in low salinity larval nurseries. Along the Ohio River, in the upper Mississippi River, the Red River, and other rivers inhabited by M. ohione in eastern North America are ancient and extensive salt deposits and salt springs (fig. 1 in Brown, 1980). Their original influence upon rivers is now greatly diminished by human impact, e.g., prevention of salt-spring flow into river waters extracted for human use. Formerly, overflow during the spring flood, when M. ohione larval release takes place, may have inundated adjacent salt deposits or salt springs to create temporary low salinity areas in which amphidromous larvae could develop.

A final hypothesis is that far-upstream populations of M. ohione are (were) "population sinks" (McDowall, 2007), i.e., stocked solely by immigration of juveniles produced by downstream coastal populations. Individuals in upstream populations might produce embryos and larvae but these would not survive to contribute to the next generation. Such population sinks have been demonstrated in amphidromous fishes in Hawaiian streams (McRae, 2007). In M. ohione, it is not known what factors might induce upstream migrating juveniles to stop and remain at a particular location or continue moving upstream. Perhaps the first juveniles that come in from the sea recruit into downstream populations. Later-arriving juveniles find the downstream habitats occupied and continue upriver until finding a location in which the local density is not too high to settle into. In this way, the latest arrivals may 
be the juveniles that continue far upstream and keep (kept) the far-upstream populations stocked with recruits. Such a situation might be evolutionarily stable if there is no opportunity for selection to operate on the timing at which juveniles begin their upstream migration.

\section{ACKNOWLEDGEMENTS}

I am grateful to editor Akira Asakura for organizing the 2009 Tokyo Crustacean meetings at which the symposium on migration of freshwater shrimps, which stimulated this paper, was presented. This research was supported by NOAA grant No. NA06OAR4170022 (R/SA-04) to RTB and Louisiana State University. This is Contribution number 138 of the University of Louisiana Laboratory for Crustacean Research.

\section{REFERENCES}

BAUER, R. T., 2004. Remarkable shrimps: adaptations and natural history of the carideans. (University of Oklahoma Press, Norman).

BAuer, R. T. \& J. Delahouss AYe, 2008. Life history migrations of the amphidromous river shrimp Macrobrachium ohione from a continental large river system. J. Crust. Biol., 28: 622-632.

Bowles, D. E., K. AzIZ \& C. L. Knight, 2000. Macrobrachium (Decapoda: Caridea: Palaemonidae) in the contiguous United States: a review of the species and assessment of threats to their survival. J. Crust. Biol., 20: 158-171.

Bracken, H. D., S. De Grave \& D. L. Felder, 2009. Phylogeny of the infraorder Caridea based on mitochondrial and nuclear genes (Crustacea: Decapoda). Crust. Issues, 18: 281308.

Bracken, H. D., S. De Grave, A. Toon, D. L. Felder \& K. A. Crandall, 2009. Phylogenetic position, systematic status, and divergence time of the Procarididea (Crustacea: Decapoda). Zoologica Scripta, 39(2): 198-212.

Brown, I. W., 1980. Salt and the eastern North American Indian: an archaeological study. Lower Mississippi Survey, Peabody Mus., Harvard Univ., Bull., 6: 1-106.

CARPenter, A., 1977. Zoogeography of the New Zealand freshwater Decapoda: a review. Tuatara, 23: 41-48.

Chace, F. A., JR. \& H. H. Hobbs, JR., 1969. The freshwater and terrestrial decapod crustaceans of the West Indies with special reference to Dominica. Bull. United States Nat. Mus., 292: 1-258.

Cook, B. D., A. W. Baker, T. J. Page, S. C. Grant, J. H. Fawcett, D. A. Hurwood \& J. M. Hughes, 2006. Biogeographic history of an Australian freshwater shrimp, Paratya australiensis (Atyidae): the role life history transition in phylogeographic diversification. Mol. Ecol., 15: 1083-1093.

Covich, A. P., T. A. Crowl, C. L. Hein, M. J. Townshend \& W. H. McDowall, 2009. Predator-prey in river networks: comparing spatial refugia in two drainage systems. Fresh. Biol., 54: 450-465. 
Covich, A. P. \& W. H. MCDowall, 1996. The stream community. In: D. Reagan \& R. WAIDE (eds.), The food web of a tropical rain forest community: 433-459. (University of Chicago Press, Chicago).

De BRUyn, M. \& P. B. MATHER, 2007. Molecular signatures of Pleistocene sea-level changes that affected connectivity among freshwater shrimp in Indo-Australian waters. Mol. Ecol., 16: 4295-4307.

De Grave, S. Y., A. CaI \& A. Anker, 2007. Global diversity of shrimps (Decapoda: Caridea) in freshwater. Hydrobiologia, 595: 287-293.

De Grave, S., N. D. Pentcheff, S. T. Ahyong, T.-Y. Chan, K. A. Crandall, P. C. Dworschak, D. L. Felder, R. M. Feldmann, C. H. J. M. Fransen, L. Y. D. Goulding, R. Lemaitre, M. E. Y. Low, J. W. Martin, P. K. L. NG, C. E. SCHWEITZER, S. H. TAN, D. TShUdy \& R. WeTZER, 2009. A classification of living and fossil genera of decapod crustaceans. Raffles Bull. Zool., (Supplement) 21: 1-114.

Dugan, C. C., R. W. Hagood \& T. A. Frakes, 1975. Development of spawning and mass larval rearing techniques for brackish-freshwater shrimps of the genus Macrobrachium (Decapoda: Palaemonidae). Florida. Res. Publ., 12: 1-28.

FRYER, G., 1977. Studies on the functional morphology and ecology of atyid prawns in Dominica. Phil. Trans. Roy. Soc. London, (B, Biol. Sci.) 277: 57-129.

HAYASHI, K.-I. \& T. HAMANO, 1984. The complete larval development of Caridina japonica De Man reared in the laboratory. Zool. Sci., 1: 571-589.

Hobbs, H. H., JR. \& C. W. HART, JR., 1982. The shrimp genus Atya (Decapoda: Atyidae). Smith. Cont. Zool., 364: 1-143.

Holmquist, J. G., J. M. Schmidt-Gengenbach \& B. Buchanan-Yoshioka, 1998. High dams and marine-freshwater linkages: effects on native and introduced fauna in the Caribbean. Cons. Biol., 12: 621-630.

Hunte, W., 1978. The distribution of freshwater shrimps (Atyidae and Palaemonidae) in Jamaica. Zool. J. Linn. Soc., 64: 35-150.

JALiHAL, D. R., K. N. SANKolli \& S. Shenoy, 1993. Evolution of larval developmental patterns and the process of freshwaterization in the prawn genus Macrobrachium. Crustaceana, 65: 365-376.

Magalhães, C. \& I. WALKer, 1988. Larval development and ecological distribution of central amazonian palaemonid shrimps (Decapoda, Caridea). Crustaceana, 55: 279-292.

March, J. G., J. P. Benstead, C. M. Pringle \& F. N. SCatena, 2003. Damming tropical island streams: problems, solutions, alternatives. Bioscience, 53: 1069-1078.

MAshiKo, K. \& J.-Y. SHY, 2008. Derivation of four morphologically affiliated species of Macrobrachium (Caridea, Palaemonidae) with divergent reproductive characteristics in northeastern Asia. J. Crust. Biol., 28: 370-377.

MCDOWALL, R. M., 2007. On amphidromy, a distinct form of diadromy in aquatic organisms. Fish \& Fisheries, 8: 1-13.

MCRAE, M. G., 2007. The potential for source-sink population dynamics in Hawaii's amphidromous fishes. Bishop Mus. Bull. Cult. Environ. Stud., 3: 87-98.

MurPhy, N. P. \& C. M. Austin, 2005. Phylogenetic relationships of the globally distributed freshwater prawn genus Macrobrachium (Crustacea: Decapoda: Palaemonidae): biogeography, taxonomy and the convergent evolution of abbreviated larval development. Zool. Scr., 34: 187-197.

Ortmann, A. E., 1894. A study of systematic and geographical distribution of the decapod family Atyidae Kingsley. Proc. Nat. Sci. Philadelphia, 1894: 397-416.

- —, 1902. The geographical distribution of freshwater decapods and its bearing upon ancient geography. Proc. American Phil. Soc., 41: 267-400. 
Page, T. J., A. M. BaKer, B. D. Cook \& J. M. Hughes, 2005. Historical transoceanic dispersal of a freshwater shrimp: the colonization of the South Pacific by the genus Paratya (Atyidae). J. Biogeogr., 32: 581-593.

Page, T. J., B. D. Cook, T. von Rintelen, K. von Rintelen \& J. M. Hughes, 2008. Evolutionary relationships of atyid shrimp imply both ancient Caribbean radiations and common marine dispersals. J. North American Benthol.Soc., 27: 68-83.

Page, T. J., K. von Rintelen \& J. M. Hughes, 2007. An island in the stream: Australia's place in the cosmopolitan world of Indo-West Pacific freshwater shrimp (Decapoda: Atyidae: Caridina). Mol. Phylog. Evol., 43: 645-659.

Pereira, G. A. \& J. V. GARCíA, 1995. Larval development of Macrobrachium reyesi Pereira (Decapoda: Palaemonidae), with a discussion on the origin of abbreviated development in palaemonids. J. Crust. Biol., 15: 117-133.

Rome, N., S. L. CONNER \& R. T. BAUER, 2009. Delivery of hatching larvae to estuaries by an amphidromous river shrimp: tests of hypotheses based on larval moulting and distribution. Freshw. Biol., 54: 1924-1932.

Truesdale, F. M. \& W. J. Mermilliod, 1979. The river shrimp Macrobrachium ohione (Smith) (Decapoda, Palaemonidae): its abundance, reproduction, and growth in the Atchafalaya basin of Louisiana, U.S.A. Crustaceana, 32: 216-220.

WiLliAMSON, D. I., 1982. Larval morphology and diversity. In: D. E. BLISS (ed.), The biology of the Crustacea. Volume 2. Embryology, morphology, and genetics: 43-110. (Academic Press Inc., New York).

Wowor, D., V. Muthus, R. Meier, M. Balke, Y. Cai \& P. K. L. NG, 2009. Evolution of life history traits in Asian freshwater prawns of the genus Macrobrachium (Crustacea: Decapoda: Palaemonidae) based on multilocus molecular phylogenetic analysis. Mol. Phyl. Evol., 52: 340-350.

First received 16 December 2009.

Final version accepted 13 January 2010. 